\title{
iPhone, iResearch. Exploring the use of smart phones in the teaching and learning of visual qualitative methodologies
}

\section{Rosalina Costa}

To cite this article: Rosalina Costa (2019): iPhone, iResearch. Exploring the use of smart phones in the teaching and learning of visual qualitative methodologies, Journal of Visual Literacy, DOI: 10.1080/1051144X.2019.1567073

To link to this article: https://doi.org/10.1080/1051144X.2019.1567073

曲 Published online: 09 Apr 2019.

Submit your article to this journal $\widetilde{ }$

View Crossmark data $\asymp$ 


\title{
iPhone, iResearch. Exploring the use of smart phones in the teaching and learning of visual qualitative methodologies Innovative teaching idea
}

\author{
Rosalina Costa \\ aUniversidade de Évora, CICS.NOVA.UÉvora - The Interdisciplinary Centre of Social Sciences \\ (Portugal), Évora, Portugal
}

\begin{abstract}
Mobile phones are a characteristic artefact of contemporary societies, transversally present in both public and private spheres, including the students' daily life. This paper showcases an innovative teaching activity that takes advantage of this fact by promoting and valuing the use of smart phones in the university classrooms, specifically when teaching and learning visual qualitative research methodologies. While collecting and interpreting data, sociology undergraduate students were invited to use their smart phones and respective apps, thus combining textual annotations with audio, photo and video recording facilities. By the end, this strategy proved to be especially important in the development of the next generation of scholars' competences to generate imaged-based records effectively and efficiently in order to answer research questions, inform interpretation and develop questions for further research.
\end{abstract}

\section{KEYWORDS}

Creative methodologies; mobile methods; qualitative inquiry; social mobile devices (SMD); visually literate student

\section{Introduction}

This article presents an innovative teaching idea developed for a course of undergraduate students in sociology focusing on qualitative analysis. Specifically, it argues the usage of smart phones and its applications for data collection and interpretation within the qualitative paradigm. Changing technologies related to data gathering in qualitative social research in an ever increasing visual and digitalized world turns this in a particularly innovative and up-to-date issue when referring to the teaching and learning processes in higher education contexts. Therefore, it is important to present and discuss both the general (dis-)advantages of using mobile phones in university classrooms while reflecting upon possibilities and methodological challenges to use smart phones and its applications in teaching and learning visual qualitative research methods. 
Introducing sociology undergraduate students in the craft of the qualitative research consists in providing them with advanced and in-depth knowledge involving the theoretical, methodological and epistemological foundations that underpin the systematic collection, processing, analysis and interpretation of qualitative data in the view of a sustained empirical understanding of social reality. The deepening of methodological skills related to the contexts and procedures of data collection and analysis are perceived to be key-competences among social scientists working within the qualitative paradigm (Clesne, 1999; Mason, 2002; Patton, 2015).

Specifically, when carrying direct observation, visual forms of data registration are often used, namely through photograph and video. Sometimes, visual materials are produced by the observed subjects themselves through elicitation techniques; other times, observed data are registered by the researchers in 'traditional' supports, such as paper notebooks using pen and pencil, but also images, making use of photographs and video cameras. Accordingly, qualitative researchers need to develop specific skills and competences to be able to analyze and interpret visual data of their research (Clesne, 1999; Silverman, 2011).

Visual literacy can be generally described as focusing on the development of specific competencies surrounding an individual's ability with visual materials and content, namely the ability to read, create, and communicate about, and through, visual content (Aiello, 2006; Ausburn \& Ausburn, 1978; Avgerinou \& Pettersson, 2011; Bamford, 2003; Fransecky \& Debes, 1972). As the contemporary multi-media world claims for visually literate persons able to understand the grammar, syntax and semantics of visual literacy (Bamford, 2003; Felten, 2008), so does current social science claim for visually literate students and (future) researchers (Creswell, 2018; Denzin \& Lincoln, 2018).

The innovative teaching activity presented hereafter follows previous and increasing research experiencing the use of mobile phones, smart phones and specific applications for mobile devices ('apps') in social research (Raento, Oulasvirta, \& Eagle, 2009), although relatively scarce in qualitative research (Beddall-Hill, Jabbar, \& Al Shehri, 2011; Garcia, Welford, \& Smith, 2016; Paulus, Jackson, \& Davidson, 2017; Sonck \& Fernee, 2013).

Smart phones can be defined as programmable mobile phones, nowadays available at an affordable cost and widely used in contemporary society. Hans Geser (2004) refers to the expansion of cell phone usage as a multidimensional challenge for sociological theory and research.

In this specific exercise, using smart phones instead of traditional instruments for collecting data was motivated by twofold criteria. On the one hand, Social Mobile Devices (SMD), particularly the mobile phone, are an artefact present in the everyday life of nowadays students, called digital natives (Prensky, 2001). Despite the controversy surrounding this concept and its opposition to 'digital immigrants' (Toledo, 2007), it is used in this paper as a way of emphasizing the 'singularity' (Prensky, 2001 , p. 1) of nowadays students in relation to education and learning. Being born in the last decades of the twentieth century, this generation was the first that grew with and surrounded by digital technology. As students are accustomed to use smart phones daily, asking them to take this object into fieldwork (instead of avoiding it) seemed a matter of practical, engaging and motivating pedagogic action. Moreover, smartphones provide some extra benefits for research and the student in 
comparison with other recording tools: smaller, more adaptable, easier to use and less intrusive in the contexts of data collection.

On the other hand, using a common and personal object for the purposes of data collection in the framework of a scientific study was a pretext for working specific questions, which are transversally important in view of the course goals, namely, the distinction between casual and systematic observation; personal and scientific use of information; ethical and unethical conduct in research.

It is worth saying that it is true that not all students own 'iPhones' yet rather quite different devices, as multiple brands of mobile phones exist in the market. Nonetheless, the title of this paper was intentionally formulated to include such a reference to 'iPhone', as a way to underline the importance of the individual in the research process. Specifically, advancing the word ' $i$ ' in 'iResearch' was used as an equivalent to an ' $I$ ', highlighting the importance of the researcher's skills and competences, who deals with different equipment when collecting and interpreting the visual.

\section{Learning objectives}

This activity was developed during the spring semester of 2018 in the framework of the course 'Qualitative Analysis Laboratory' (LABQUAL) [SOC2413], taught to sociology undergraduate students at the University of Évora (Portugal).

In LABQUAL course, specific learning objectives regarding visual literacy development are included in the syllabus and explored through an original exercise performed in small groups along the semester. Therein, students are invited to collect data through multiple forms, including the visual, thus exercising different and complex 'ways of seeing' social reality (Berger, 1972).

Specific learning objectives regarding visual literacy development in this course include (1) to develop students' competences to design a qualitative inquiry, determining in advance the quality and scope of the visual materials they need; (2) to increase students' ability to generate imaged based records and contents of visual media effectively and efficiently in order to answer research questions; (3) to increase the visual literacy skills of students for identifying, describing and interpreting visual information (people, places, things, and ideas) of images and visual media, examining the relationship of images to each other, and using related images to inform interpretation; (4) to use images and visual media effectively in scientific reports, recognizing when more information about an image is needed, developing questions for further research, and conducting additional research as appropriate; (5) to include textual information as needed to convey an image's meaning (for example, using captions, referencing figures in a text, incorporating keys or legends); (6) to usefully communicate image content via textual descriptions and design meaningful visual media content; and (7) to become aware of the ethical, legal, social and economic dimensions of images and visual media, and to use visual materials through an ethical approach.

\section{Detailed activity description}

In the 2017/2018 academic year, LABQUAL students developed several exercises pertaining to understand the social processes that construct, sustain and 
reproduce local gastronomy as both a product and producer of culture. Locally engaged in the Portuguese Alentejo region, first, students organized in small groups carried on individual semi-structured interviews. In a second phase, students were invited to understand the practices and meanings of the local gastronomy. For such, students asked the interviewees for their favourite traditional dish and asked if they could observe its cooking process, including shopping, food preparation and serving.

Students agreed with individuals the time and place to carry the observation and before going into the field they elaborated an observation plan comprising and adjusting the precise objectives (deriving from the general and common research question); the team of researchers (name and specific tasks for each student, namely who would be responsible for interacting with those being observed and who would be observing what and photographing, video recording or taking textual notes), timing of the observation (temporal and spatial coordinates of observation) and specific topics of visual communication to observe (what exactly to observe, such as objects, signs, symbols, colours, smells, textures, gestures, expressions, processes, sequences and movements).

Students developed periods of observation in the domestic space of the observed people, namely in their kitchens, in order to accompany the entire preparation of a traditional dish. Some students also accompanied those observed for shopping the day before, as specific and fresh products had to be bought and prepared in advance.

Instead of using 'traditional' instruments of observation, such as paper notebooks, camera, video camera and audio recorder, and as students have their own devices which usually use and whose features know well, they were challenged to use their smart phones as a privileged instrument of data collection during the observation exercises.

By the end, the exercise allowed students to increase data previously collected through semi-structured interviews with the direct observation of movements, smells and sounds related with the cooking and serving processes. Students registered all this information through many forms, namely with textual free notes, photography, audio and video capturing, which allowed for a thick description written down during and after the observation.

\section{Learning outcomes}

After the observation, students prepared a written report in which they had to present, analyze and interpret the different materials collected. Such a report resulted in a visually informed document in which students ultimately answered the research question.

Among the various learning objectives set out above, this exercise proved to be especially important in the development of students' competences to generate imaged based records effectively and efficiently in order to answer research questions, inform interpretation and develop questions for further research.

First, as metaphorically shown in Figure 1, using the smart phone allowed students to meet a multitude of perspectives that need to be compared and contrasted with 


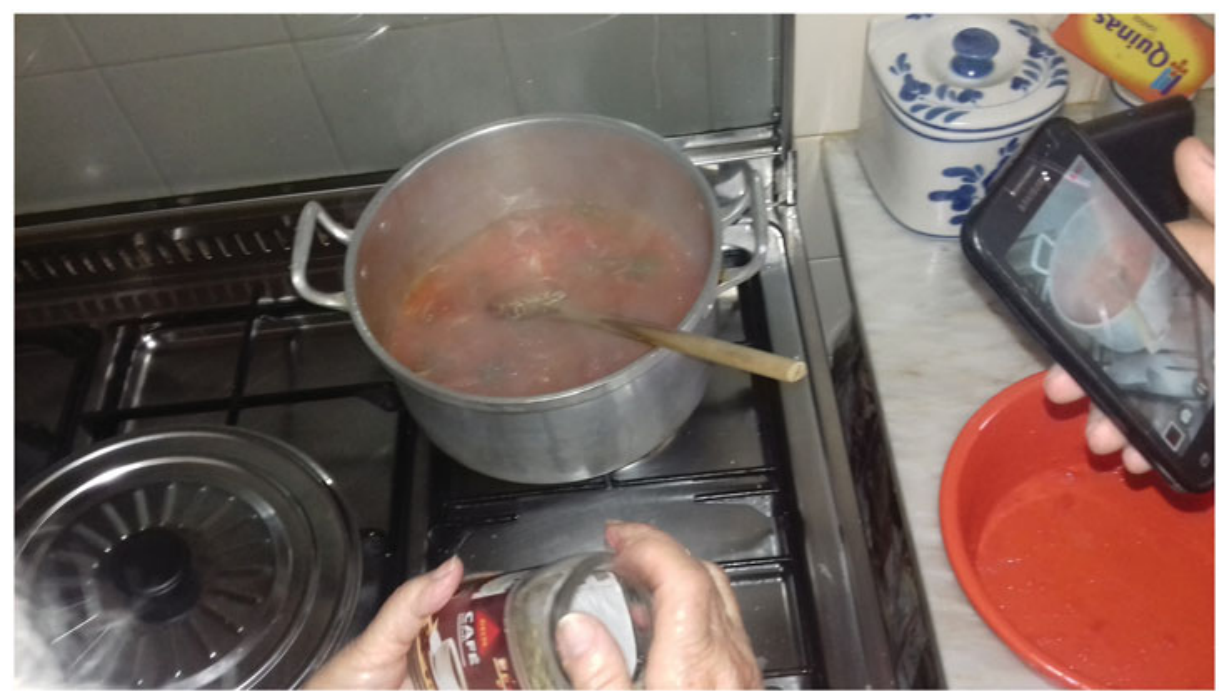

Figure 1. Using the smartphone to capture the complexity of cooking practices. Photo by D. Rodrigues, F. Lúcio, and J. Rocha (2018).

each other and with complimentary information (e.g. smart phone images captured by observer no. 1, on the right; image captured by observer no. 2, in front; oral narrative captured by observer no. 3; global view obtained through constant comparison, etc.)

Moreover, as illustrated in Figure 2, observation notes taken by the students in the smart phones as 'free notes' can be easily edited and later included as valuable textual information to convey an image's meaning, thus revealing to be 'smart'.

Being attentive to the heuristic potential of the visual on seemingly anodyne artefacts, such as the ticket of the butchery row in the supermarket shown in Figure 3, can be a way of usefully communicate the different times and rhythms the researcher faces during observation, which are made of both advances and waits, words and silences, visible and latent actions and meanings.

Finally, training visually literate students prepare future scholars to identify, describe and argue for the multiple layers of meaning behind given visual information. For instance, being confronted with the final presentation of a 'traditional dish' such as the 'Gaspacho à Alentejana' (see Figure 4), challenges students to seek meaning beyond what their eyes see, namely, to search for the meanings of 'tradition', 'authenticity' or 'aesthetics' in everyday life' cooking practices.

At the end of the semester, a public presentation of the exercises was prepared, for which students prepared small videos (not exceeding five minutes length). Using their own specific software knowledge and competences, students took advantage of the different kinds of data gathered throughout the project: interview transcriptions, photographs, video, spatial sketches and complementary materials obtained through documental research. ${ }^{1}$

Students were evaluated based on both the written report and the public presentation. Specific criteria for the evaluation comprised the correctness (using a quantitative evaluation scaled $0-20$ ) in achieving the several learning objectives regarding visual 


\title{
Observação de laboratório qualitativo
}

\author{
O senhor mostrou todo o interesse, vestiu \\ a sua bata com o seu nome gravado "chefe \\ j.f." \\ Usa azeite típico do Alentejo - fala sobre a \\ sua história. \\ Tem os ingredientes todos preparados \\ antes de começar a confeccionar. \\ Começa por fritar o chouriço, retira \\ enquanto baixa o lume, do molho tira um \\ pouco para o tacho e põe o toucinho \\ entremeado na frigideira. Utilizou o que \\ tinha em casa. O toucinho seca e fica \\ estaladiço. Quando está douradinho \\ retira. Mistura cebola e alho num tacho. \\ Reserva o louro para depois. Refoga a \\ cebola e o alho. \\ Depois da cebola lourinha, acrescenta o \\ $+\quad$ Editado em 09:33
}

Figure 2. 'Free' notes captured in the smart phone. Photo by A. Jordão, J. Candeias, and S. Silva (2018).

literacy development as presented before. The assessment findings, broadly positive, are highly consistent with the argument against the effectiveness of the exercise in meeting the underlying pedagogical goals. With varying degrees of success, and specifically as far as visual literacy is concerned, the described exercise allowed to elevate the students' competences related to the collection of data, organization and writing of scientific reports on qualitative research, and to develop effective ways of disseminating results for scientific research to both the scientific community and the general public.

\section{Possibilities and limitations}

The exercise described in this paper outlines a specific activity aiming to take advantage of the use of smart phones for the purposes of increase students' visual literacy regarding scientific research, as part of a qualitative method's course aimed at secondyear undergraduate sociology students. The main expected outcome with this exercise included the in-depth learning and training of the skills and competences required for a qualitative researcher, as presented in the course syllabus, making use of a very 


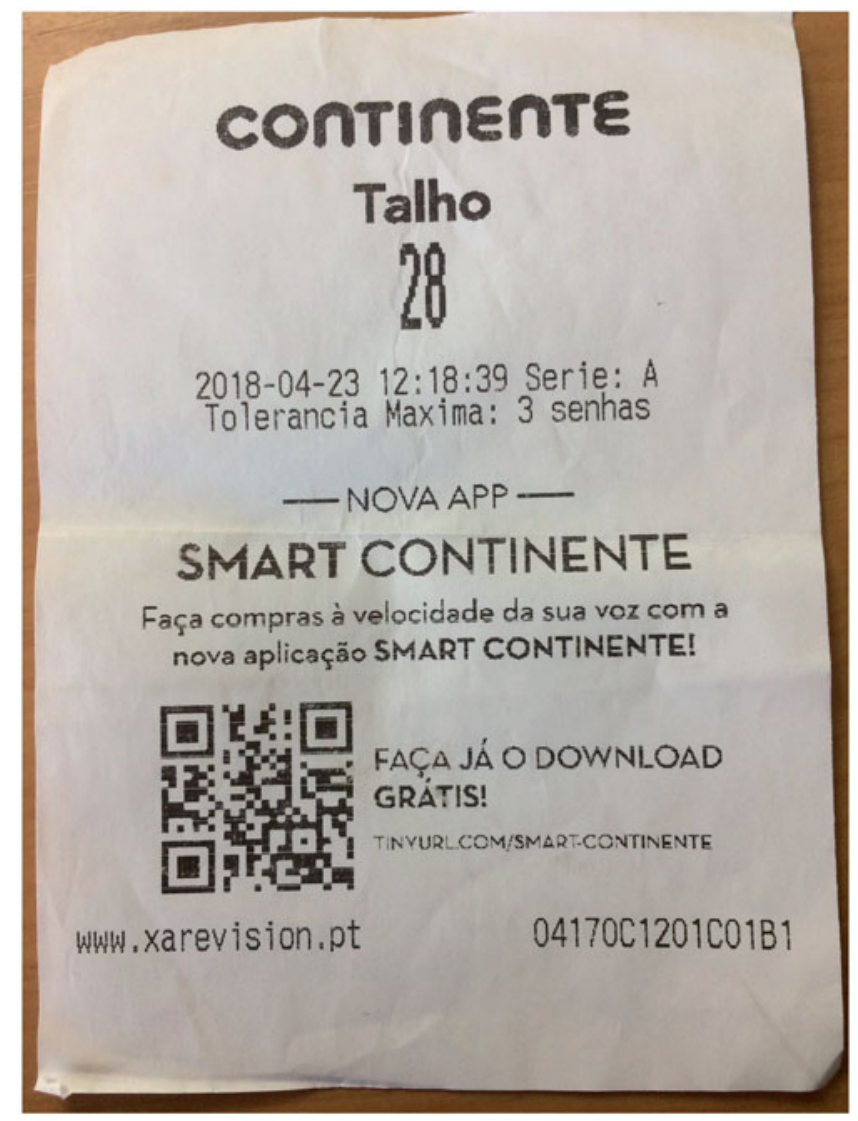

Figure 3. Ticket of the butchery row in the supermarket while shopping. Photo by I. Silva, R. Lobo, and S. Carvalho (2018).

quality and time and cost-effective solution. Transversally, this exercise also meets an unspoken goal regarding the motivation of undergraduate students of sociology as a result of engaging them in the field by using their own mobile phones as research tools.

Main limitations deriving from the use of mobile phones for collecting data for scientific research have to be posed in three different moments: data collection and archiving, data analysis and data presentation.

First, students should carefully explain to those observed that the mobile phone, being mostly a personal equipment, is going to be used for the scientific collection of data. As in some cases, the use of a mobile phone might not seem to be so professional as a microphone or camera, in some other cases, the association to a personal object and easy sharing of information might cause some discomfort or suspicion among those being observed. Moreover, as the mobile phone is used for the main purpose of making and receiving calls, it is important to prepare students to deactivate other functions while using it for collecting data. Specifically, students should ensure that the mobile phone has sufficient battery and activate the airplane mode and deactivate notifications (e.g. from social media) that somehow could distract them 


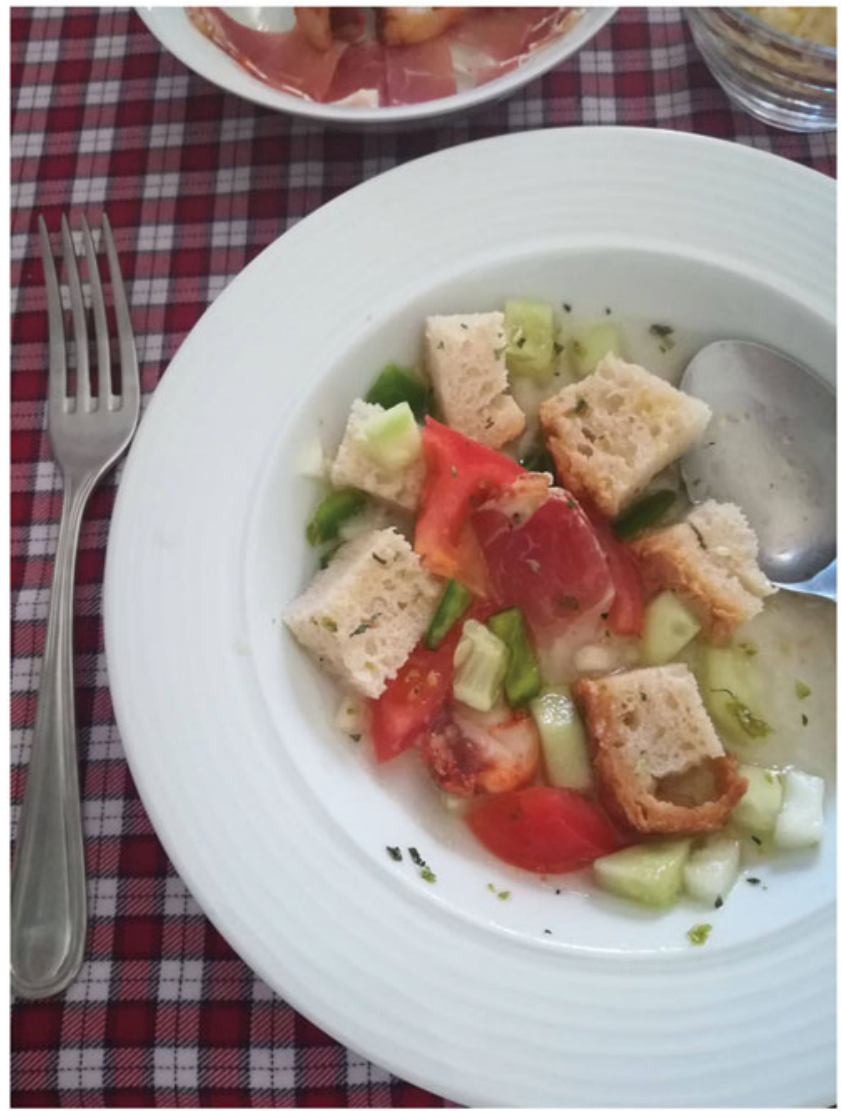

Figure 4. 'Gaspacho à Alentejana', Alentejo tradicional dish. Photo by A. Oliveira, J. Tirapicos, and L. Gusmão (2018).

while collecting data. Regarding archiving, it is important to safeguard that the mobile phone has enough space to record all observations, noting especially that high-quality photographs, audio and video recordings are particularly demanding in terms of disk storage. Moreover, students should ensure the safety of the equipment, data integrity from its misuse or neglect and provide immediately copies of the materials after observation periods, either through a copy into other supports or sending materials for trusted colleagues by e-mail or using data synchronization and cloud sharing.

Second, data analysis of different visual materials raises specific questions when organizing, systematizing and writing about the results. The use in classes of CAQDAS - Computer-Assisted Qualitative Data Analysis Software, specifically the qualitative software NVivo11 (C) QSR International), is particularly suited for managing different visual materials, allowing for a fast, systematic and deep analysis of data, otherwise difficult to manage manually.

Third, regarding data presentation, writing a paper or preparing a short video teaser calls for a close attention with ethical questions related to the source of data, and specifically with the distinction, that should turn out very clear, between original and transformed data. According to broader guidelines to conduct social research (ISA, 2001), it is important to guarantee the protection of the respondents' personal 
information and to be sure that the right authorization was conveniently asked and obtained previously to data collection. This way, students can effectively preserve privacy and the individuals' anonymity where necessary in all supports of data presentation.

\section{Potential application of the activity in other fields of study}

The potential of grouping textual memos with photographs, audios and videos and easily archiving it with enough contextual information (e.g. real-time information such as hour, date, GPS references) turns mobile and smart phones and its apps into multifunctional and fruitful tools to enhance scientific research in many other fields of study.

It is noteworthy that while this pedagogical experience engaged students in a dynamic and creative process of observation and data collection in the view of the specific course for which it was designed, it has a strong potential of transferability to various disciplines where the observation of places, people and activities may arise as a key and cross-competence in the teaching-learning process, besides sociology (e.g. anthropology, psychology, geography, architecture, urban studies, etc.).

In short, whether this exercise had valuable benefits for a specific teaching and learning experience, it can as well be adapted and replicated as an innovative and fruitful way to boost opportunities for a visually, critically and creative engagement between students and the social reality they are studying, and to develop a greater understanding of visual materials among individuals - and researchers - living in an increasing visual and digitalized world.

\section{Note}

1. This presentation took place on 8 June 2018 at the University of Évora. A teaser for that public presentation was prepared by the teacher and is available online, on Youtube, at https://www.youtube.com/watch?v=yLkP4izVSEg\&feature=youtu.be

\section{Acknowledgements}

The author gratefully acknowledges the dedication and enthusiasm of all students who participated in the spring semester of 2018 in the course 'Qualitative Analysis Laboratory' (LABQUAL) [SOC2413], taught to sociology undergraduate students at the University of Évora (Portugal), as well as to the anonymous reviewers and the editors of this volume for their attentive and useful comments and suggestions.

\section{Disclosure statement}

No potential conflict of interest was reported by the author. 


\section{References}

Aiello, G. (2006). Theoretical advances in critical visual analysis: perception, ideology, mythologies, and social semiotics. Journal of Visual Literacy, 26, 89-102. doi:10.1080/23796529. 2006.11674635

Ausburn, J.L., \& Ausburn, F.G. (1978). Visual literacy: background, theory, and practice. Programmed Learning \& Educational Technology, 15, 292-297. doi: 10.1080/ 0033039780150405

Avgerinou, M.D., \& Pettersson, R. (2011). Toward a cohesive theory of visual literacy. Journal of Visual Literacy, 30, 1-19. doi:10.1080/23796529.2011.11674687

Bamford, A. (2003). The Visual Literacy White Paper. Retrieved from: http://wwwimages.adobe. com/content/dam/Adobe/en/education/pdfs/visual-literacy-wp.pdf

Beddall-Hill, N., Jabbar, A., \& Al Shehri, S. (2011). Social mobile devices as tools for qualitative research in education: iPhones and iPads in ethnography, interviewing, and design-based research. Journal of the Research Center for Educational Technology, 7, 67-90. Retrieved from http://eprints.hud.ac.uk/id/eprint/10507

Berger, J. (1972). Ways of seeing. London: Penguin.

Clesne, C. (1999). Becoming qualitative researchers. An introduction (2nd ed.). New York: Longman.

Creswell, J. (2018). Research design. Qualitative, quantitative, and mixed methods approaches (5th ed.). Los Angeles: Sage Publications.

Denzin, N., \& Lincoln, Y. (Eds.). (2018). The Sage handbook of qualitative research (5th ed.). Los Angeles: Sage Publications.

Felten, P. (2008). Visual literacy. Change: The Magazine of Higher Learning, 40, 60-64. doi: 10.3200/CHNG.40.6.60-64

Fransecky, R.B., \& Debes, J.L. (1972). Visual literacy: A way to learn, a way to teach. Washington, DC: AECT Publications.

Garcia, B., Welford, J., \& Smith, B.M. (2016). Using a smartphone 'app' in qualitative research: the good, the bad and the ugly. Qualitative Research, 16, 508-525. doi:10.1177/1468794115593335

Geser, H. (2004). Towards a sociology of the mobile phone. In Sociology in Switzerland: Sociology of the Mobile Phone. Online Publications. Zurich: University of Zurich, May 2004 (Release 3.0). Retrieved from: http://socio.ch/mobile/t_geser1.pdf

ISA. (2001). Code of Ethics of the International Sociological Association. Madrid: ISA. Retrieved from http://www.isa-sociology.org/about/isa_code_of_ethics.htm

Mason, J. (2002). Qualitative researching (2nd ed.). London: Sage Publications.

Patton, M.Q. (2015). Qualitative research \& evaluation methods: Integrating theory and practice (4th ed.). Los Angeles: Sage Publications.

Paulus, T.M., Jackson, K., \& Davidson, J. (2017). Digital tools for qualitative research: disruptions and entanglements. Qualitative Inquiry, 23, 751-756. doi:10.1177/1077800417731080

Prensky, M. (2001). Digital natives, digital immigrants, part 1. On the Horizon, 9, 1-6. doi:10.1108/ 10748120110424816

Raento, M., Oulasvirta, A., \& Eagle, N. (2009). Smartphones: an emerging tool for social scientists. Sociological Methods and Research, 37, 426-454. doi:10.1177/0049124108330005

Silverman, D. (2011). Interpreting qualitative data: $A$ guide to the principles of qualitative research (4th ed.). Los Angeles: Sage Publications.

Sonck, N., \& Fernee, H. (2013). Using smartphones in survey research: A multifunctional tool. Implementation of a time use app; a feasibility study. Den Haag: The Netherlands Institute for Social Research | SCP.

Toledo, C.A. (2007). Digital culture: immigrants and tourists responding to the natives' drumbeat. International Journal of Teaching and Learning in Higher Education, 19, 84-92. 